\title{
Current Munich status concerning in-vivo optical coherence tomography for differentiating lesions of the upper aerodigestive tract
}

\author{
Veronika Volgger ${ }^{1 *}$, Herbert Stepp ${ }^{1}$, Waseem Jerjes² ${ }^{2}$ Tahwinder Upile ${ }^{2}$, Andreas Leunig ${ }^{1}$, Colin Hopper ${ }^{2}$, \\ Christian Betz ${ }^{1}$
}

From 2nd Scientific Meeting of the Head and Neck Optical Diagnostics Society

San Francisco, CA, USA. 23-24 January 2010

\section{Objective}

Non-invasive differentiation of pre- and early malignant mucosal changes may be helpful to reduce the morbidity and shorten the time to diagnosis for the patients concerned. Optical Coherence Tomography (OCT) seems to be well suited to reach this goal.

\section{Methods}

61 patients with a total of 82 primary leukoplakic or erythroplakic mucosal lesions of the upper aerodigestive tract (OADT) were prospectively examined using an in-vivo, time-domain OCT (Niris ${ }^{\circ}$ Imalux Corporation, USA; lateral resolution $25 \mu \mathrm{m} /$ axial resolution $15 \mu \mathrm{m}$ ) so far. The results were subsequently correlated to histopathology of tissue biopsies taken from the same areas. Additionally, intensity profiles of OCT images were evaluated concerning their ability to differentiate dysplasia from hyperplasia.

\section{Results}

Down to a depth of $1.5 \mathrm{~mm}$, microanatomical structures were clearly identifiable on the OCT images. Concerning the ability to differentiate non- and early invasive lesions, OCT reached a sensitivity of $100 \%$ and a specificity of $92 \%$ or $75 \%$ (investigator unblinded or blinded to visual inspection), respectively. False positive findings were mostly hyperplastic lesions with a significant broadening of the epithelial layer. Epithelial thicknesses measured on OCT images and histological slides correlated well $(\kappa=0.63)$, but were no indicators of either epithelial hyperplasia or different grades of dysplasia.

'Department of Otorhinolaryngology, Head and Neck Surgery, Ludwig Maximilian University, Munich, Germany

Full list of author information is available at the end of the article
Yet, OCT intensity profiles showed a statistically significant difference between dysplastic and hyperplastic lesions in a subset of cases $(n=44)$.

\section{Conclusions}

The method seems highly promising for early, non-invasive tumour diagnosis in the UADT. Technical advances and an increase in patient numbers will help to define its clinical value in the near future.

\section{Author details}

'Department of Otorhinolaryngology, Head and Neck Surgery, Ludwig Maximilian University, Munich, Germany. ${ }^{2}$ UCL Department of Surgery, University College London Medical School, London, UK .

Published: 29 October 2010

doi:10.1186/1758-3284-2-S1-039

Cite this article as: Volgger et al:: Current Munich status concerning invivo optical coherence tomography for differentiating lesions of the upper aerodigestive tract . Head \& Neck Oncology 2010 2(Suppl 1):039.

Submit your next manuscript to BioMed Central and take full advantage of:

- Convenient online submission

- Thorough peer review

- No space constraints or color figure charges

- Immediate publication on acceptance

- Inclusion in PubMed, CAS, Scopus and Google Scholar

- Research which is freely available for redistribution 